\title{
VETERINARY SCIENCE AND ANIMAL HUSBANDRY TOPOGRAPHY AND MORPHOLOGY OF THORACO- CERVICAL LYMPH NODES OF DOMESTIC GEESE
}

\author{
V. V. MELNYK, Candidate of Veterinary Sciences \\ Associate Professor, Department of Epizootology, Microbiology and Virology \\ https://orcid.org/0000-0002-6958-2577 \\ T. S. MARKOVSKA, Veterinarian \\ https://orcid.org/0000-0001-6172-457X \\ National University of Life and Environmental Sciences of Ukraine, Kyiv, Ukraine \\ E-mail:melnyk_vv@nubip.edu.ua,
}

\begin{abstract}
It is established that in geese, are constantly registered only cervicothoracic lymph nodes. The cervicothoracic lymph nodes of geese are local accumulations of lymphoid tissue in the wall of the lymphatic vessels, which are taking away lymph from the head and neck. The cervicothoracic lymph nodes of geese are not the same shape, most of them have a conical shape. Parameters of absolute, relative weights, and size of the cervicothoracic lymph nodes of geese depend on the weight and sizes of their body.

The cervicothoracic lymph nodes of geese are formed by a connective tissue stroma, parenchyma, and sinus. Connective tissue stroma is represented by a capsule, which is a continuation of the adventitia and media of lymphatic vessels and trabeculae. Connective tissue stroma is formed by loose fibrous connective tissue, which has blood vessels and myocytes. Sinus is a continuation of the lymphatic vessel lumen and its wall - a continuation of its intima. The area, occupied by a connective tissue stroma, parenchyma, and sinus in the nodes of investigated birds, varies. The largest area occupies the parenchyma of the cervicothoracic lymph nodes, which like the parenchyma of lymph nodes in mammals, is formed by lymphoid tissue. In the parenchyma, there is unclearly allocated the cortical and cerebral substances. The cortical substance is located on the periphery and the cerebral substance - around the sinus. The area of the cortical substance dominates over a cerebral substance. The cortical substance is formed by the diffuse lymphoid tissue and lymphoid nodules (mainly secondary), and the cerebral substance - only by the diffuse lymphoid tissue. Lymphoid nodules are spherical in shape, surrounded by delicate shells, and depending on the diameter, is divided into three groups: large, medium, and small. The basis of the lymphoid tissues in the parenchyma is reticular tissues, which consists of reticular fibers. The architectonics of its fibers varies in the different components of the lymphoid tissue. They are placed tightly, intertwined, and form the confined units of various shapes and small sizes. The cellular composition of the parenchyma of the cervicothoracic lymph nodes of geese is extremely diverse. It is reticulocytes, lymphocytes, immunoblasts, macrophages,
\end{abstract}


monocytes, plasma cells, mast cells, and myoid cells. The content of these cells is not the same. The presence of lymphocytes, immunoblasts, macrophages, and plasma cells in the parenchyma of the cervicothoracic lymph nodes of geese convinces in their functioning as peripheral organs of immunogenesis.

Keywords: geese, cervicothoracic lymph nodes, connective tissue stroma, parenchyma, central sinus, cortical substance, medullary substance, lymphoid follicles, lymphoid cells

\section{Introduction}

Lymph nodes are the peripheral organs of haematopoiesis and immunogenesis (Sapin et al., 1978; Vershigora, 1990). In them, due to antigenic stimulation, T- and B-lymphocytes differentiate into the effector cells, which cause specific immunity. Besides, in these bodies, there is a release of lymph from the foreign substances and its deposition, recirculation of lymphocytes, an metabolism of some substances. They, owing to availability in their connective tissue stroma of smooth myocytes, also promote lymph circulation (Vinogradova, 1970; Sapin, 1977; Sapin, 1978; Sapin et al., 1978; Vershigora, 1990).

\section{Analysis of recent researches and publications}

During the historical development of animals for the first time lymph nodes appear in waterfowl (Sapin et al., 1978). They are found in geese, ducks, flamingos, and are presented by two couples: the cervicothoracic and lumbar (Jolly, 1909-1910; Ellenbergez \& Baum, 1915; Kositsyn, 1958; Kositsyn, 1959; Kositsyn, 1963; Florensov, 1968; Florensov \& Pestova, 1990). References about the existence of lumbar lymph nodes at waterfowls are inconsistent. There are data that geese and ducks don't have them and that they are assimilated with kidneys (Pylypenko \& Musienko, 1973; Berezina, 1979).
The topography and morphology of the cervicothoracic lymph nodes of birds are studied insufficiently. Due to this, the data of their functional features are incomplete and contradictory.

The purpose of the study - to clarify the topography of the cervicothoracic lymph nodes of geese at the age of puberty, to establish their macroscopic morphological parameters, and to find out features of the microscopic structure.

\section{Materials and methods of research}

Material for studying was selected from 13 geese of Gorki Goose breed at the age of 11 months which grew up in farms of Kyiv region (Ukraine). To perform the work, the classical methods of macroscopic and microscopic morphological studies (Merkulov, 1969; Avtandilov, 1990; Goralsky et al., 2005) were used. After the slaughtering of birds by an acute devascularization, the topography, shape, color, texture, absolute and relative organ weight, and linear morphometric parameters were defined. For the investigation of the cellular composition of lymph node parenchyma, the imprint preparations were prepared. The materials selected for microscopic examination were fixed in a $10 \%$ aqueous solution of neutral formalin for 5 days. From the fixed material were cut indi- 
vidual pieces, which were dehydrated in ethyl alcohol with the increasing strength and embedded in paraffin. The obtained paraffin blocks were sliced by microtome MPS-2 with a thickness of 3-8 microns. Slices were stained with hematoxylin and eosin, and by Weigert and van Gizon. The composition of parenchyma cells, their structure, and content were determined by histological preparations stained with azure II and eosin, imprint preparations stained according to Pappenheim, and by electron microscopy according to the $\mathrm{V}$. Uikly method (Goralsky et al., 2005).

Bright-field microscopes "Olympus", "Biolar", MBI-15 MBI-6-1, and MBS-1 were used for microscopic studies. The area to be occupied in the lymph nodes of individual structural components were determined using a microscope MBS-1 and the measuring grid, which is a part of its set.

\section{Results of the research and their discussion}

The performed researches confirmed the data (Khomych \& Melnyk, 2008; Melnyk, 2010), that the cervicothoracic lymph nodes of geese are paired constant bodies. They are located under the skin in a lower part of the neck, at the top of the angle which is formed by the jugular and subclavian veins (before the entry of a jugular vein into a thoracoabdominal cavity) (Fig. 1). Lymph nodes are covered with many layers of fatty tissue that complicate their detection, preparation, and differentiation from a number of the located last lobes of the thymus.

The cervicothoracic lymph nodes have different forms. They may be cone-shaped $(80 \%)$ and spindle-shaped (20\%). Their colours are pink and grey, and consistency is dense.
The absolute weight of the right and left lymph nodes is the same $(0.28 \pm 0.06 \mathrm{~g})$, and the relative weight of the first $(0.009 \pm 0.001 \%)$ is bigger than the second $(0.008 \pm 0.001 \%)$.

The length of the right lymph node $(25.68 \pm 2.20 \mathrm{~mm})$ is bigger than the left $(22.85 \pm 1.56 \mathrm{~mm})$. Width in the area of expansion: the right $-4.65 \pm 0.47 \mathrm{~mm}$, the left $-5.46 \pm 0.59 \mathrm{~mm}$. The width of the restriction: the right $-2.69 \pm 0.38 \mathrm{~mm}$, the left $3.34 \pm 0.49 \mathrm{~mm}$. The thickness of the lymph nodes: the right $-2.038 \pm 0.242$ $\mathrm{mm}$, the left $-2.331 \pm 0.345 \mathrm{~mm}$.

The cervicothoracic lymph nodes of geese located in a wall of lymphatic vessels, which are taking away lymph from the head and the neck, and in a formation of their components, except for lymphoid tissue, participate all structures of these vessels. They are formed by a connective tissue stroma and parenchyma of the central sinus. Connective tissue stroma occupies $23.95 \pm 0.95 \%$ of the area of nodes, parenchyma $-55.48 \pm 1.45 \%$, and the sinus $-20.57 \pm 0.66 \%$.

Connective tissue stroma is presented by a capsule and a few trabeculae (Fig. 2). The capsule is a continuation of adventitia and media of a lymphatic vessel. In comparison with them, it is thickened. Trabeculae extend from the capsule into the parenchyma of the nodes. They do not have a specific orientation and do not reach the walls of the sinus. Connective tissue stroma is formed by loose fibrous connective tissue with its characteristic cells and intercellular substance. The stroma contains bundles of single bunches of myocytes and blood vessels.

Sinus occupies a central position in the lymph nodes. It is a continuation of the lumen of the lymphatic vessel and its wall a continuation of its intima (Fig. 3).

The wall of the sinus is formed by a layer of endothelial cells and a subendothe- 


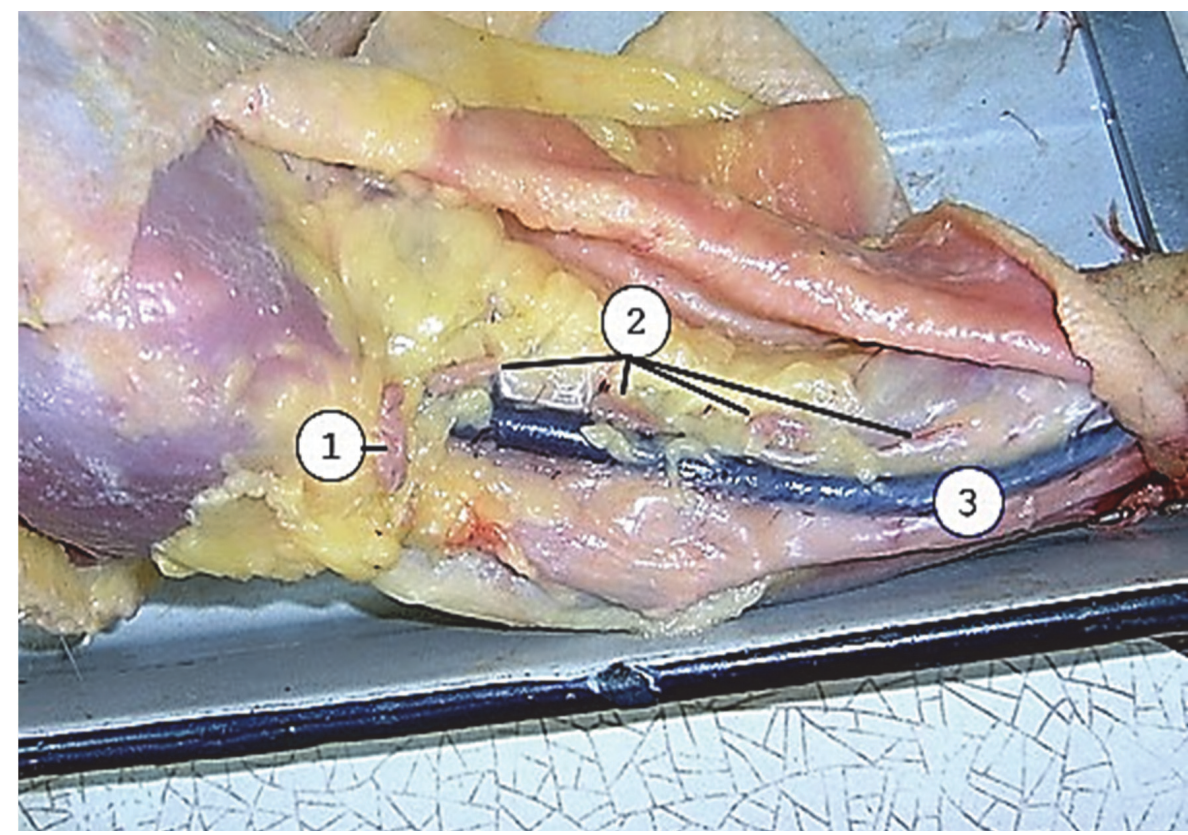

Fig. 1. Topography of the cervicothoracic lymph nodes of a domestic goose.

Macropreparations: 1 - lymph node; 2 - thymus lobes; 3 - jugular vein

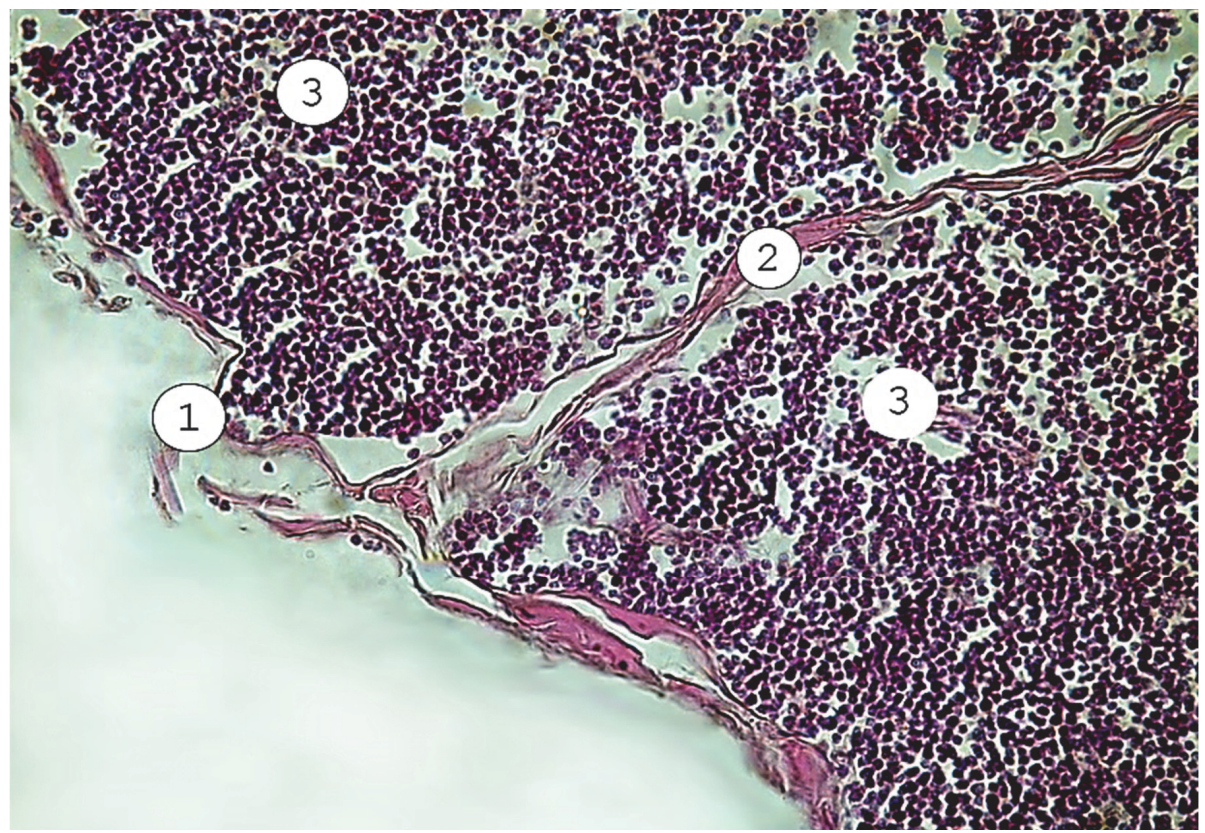

Fig. 2. Connective tissue stroma of the cervicothoracic lymph node of a domestic goose. Histological preparation (hematoxylin and eosin, $x$ 200): 1 - capsule; 2 - trabeculae; 3 - parenchyma 
lial layer. The structure of these endothelial cells is similar to the cells of lymphatic vessels in mammals. In some places between the endothelial cells, there are significant cracks through which there is a migration of lymphoid cells into the lumen of the sinus. We didn't find the basal membrane under endothelial cells. The subendothelial sinus wall layer is formed by a soft layer of a loose fibrous connective tissue. Among its fibers, we found the only collagen, which in places, are connecting with the outer surface of the endothelial cells. Axons of the reticular cells of a node's parenchyma penetrate the subendothelial layers. Sinus varies in width. In some places its' wall penetrates a node's parenchyma, forming deepings of various shapes and sizes.

In a sinus lumen, there are fragments of disrupted cells, surrounded by a membrane, lymphoid cells, and single erythrocytes.
The parenchyma of lymph nodes is located between a wall of a sinus and components of connective tissue stroma. Its basis is formed by lymphoid tissue. In the parenchyma, there is unclearly stand out the cortical and cerebral substances. The first is located on the periphery, the second - around the sinus and its invaginations. The area of the cortical substance $(57.99 \pm 1.21 \%)$ dominates under a cerebral substance $(42.01 \pm 1.21 \%)$. The cortical substance is formed by the diffuse lymphoid tissue and lymphoid nodules (mainly secondary), and the cerebral substance - only by the diffuse lymphoid tissue (Fig. 4). Lymphoid nodules are predominantly spherical in shape, have an unequal diameter, and are surrounded by delicate shells. Depending on the diameter, we divided them into a small (58.79 \pm $1.37 \mathrm{~mm})$, medium $(165.51 \pm 1.93 \mathrm{~mm})$, and large $(253.16 \pm 3.43 \mathrm{~mm})$.

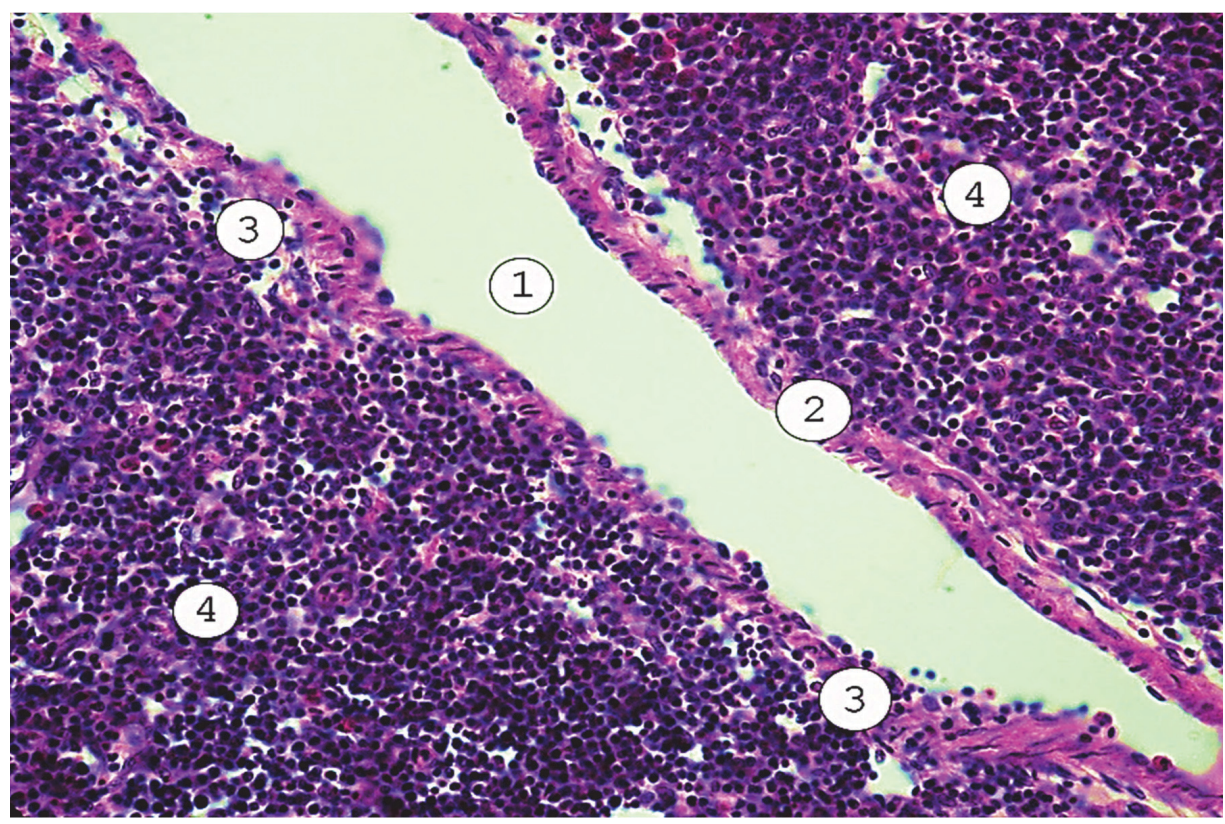

Fig. 3. Central the cervicothoracic sinus node of a domestic goose. Histological preparation (hematoxylin and eosin, $\times 200$ ): 1 - lumen of the sinus; 2 - wall of the sinus; 3 - invaginations; 4 - node parenchyma 


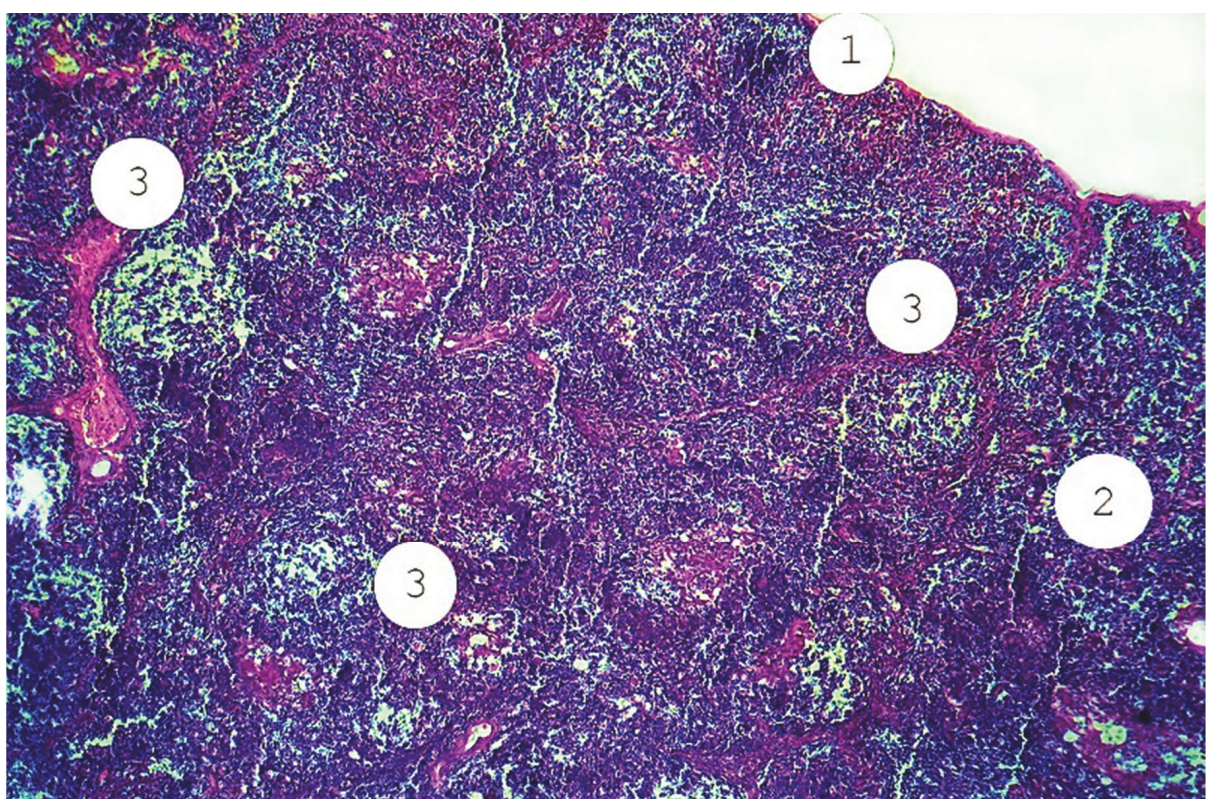

Fig. 4. Cortical substance of the cervicothoracic lymph node of a domestic goose. Histological preparation (hematoxylin and eosin, $x$ 100): 1 - capsule; 2 - diffuse lymphoid tissue; 3 - lymphoid nodules

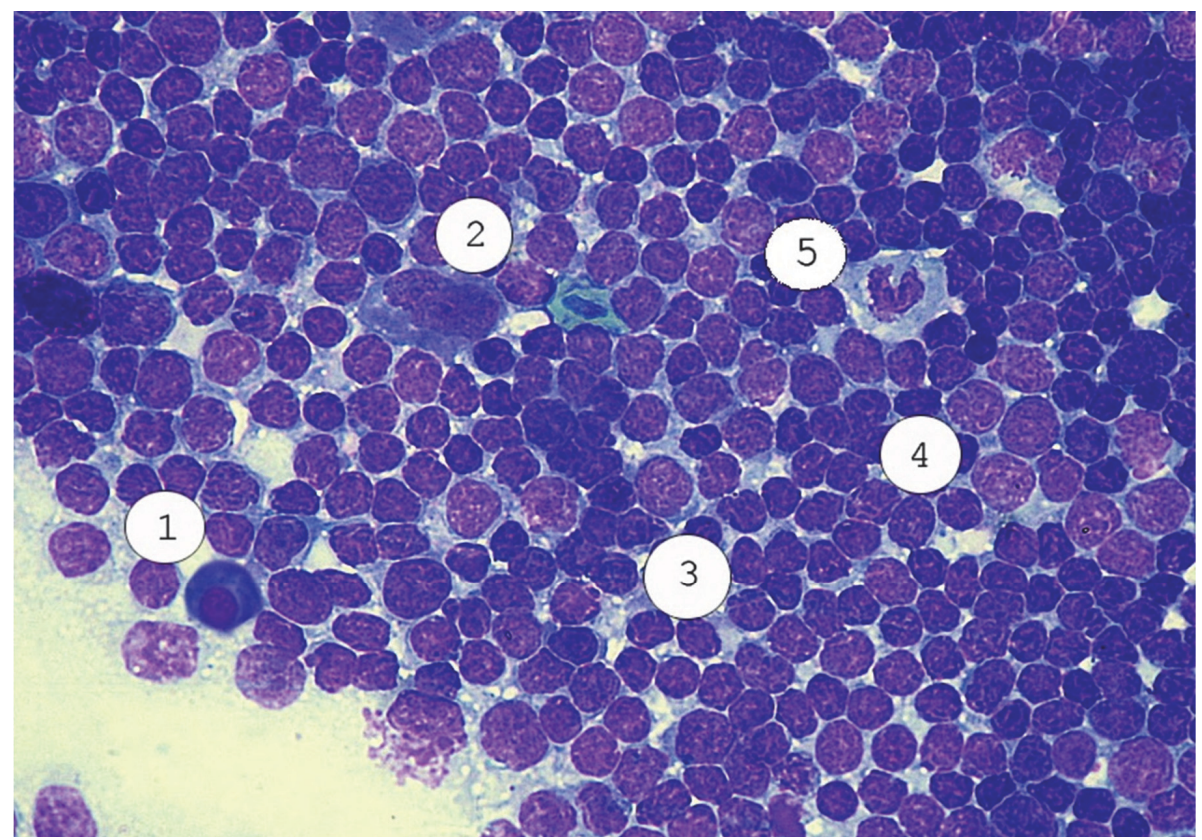

Fig. 5. Parenchyma cells of lymph node of a domestic goose. The preparations (imprint stained by Pappenheim, × 1000): 1 - plasmocytes; 2 - macrophage; 3 large lymphocytes; 4 -medium lymphocytes; 5 - monocyte 


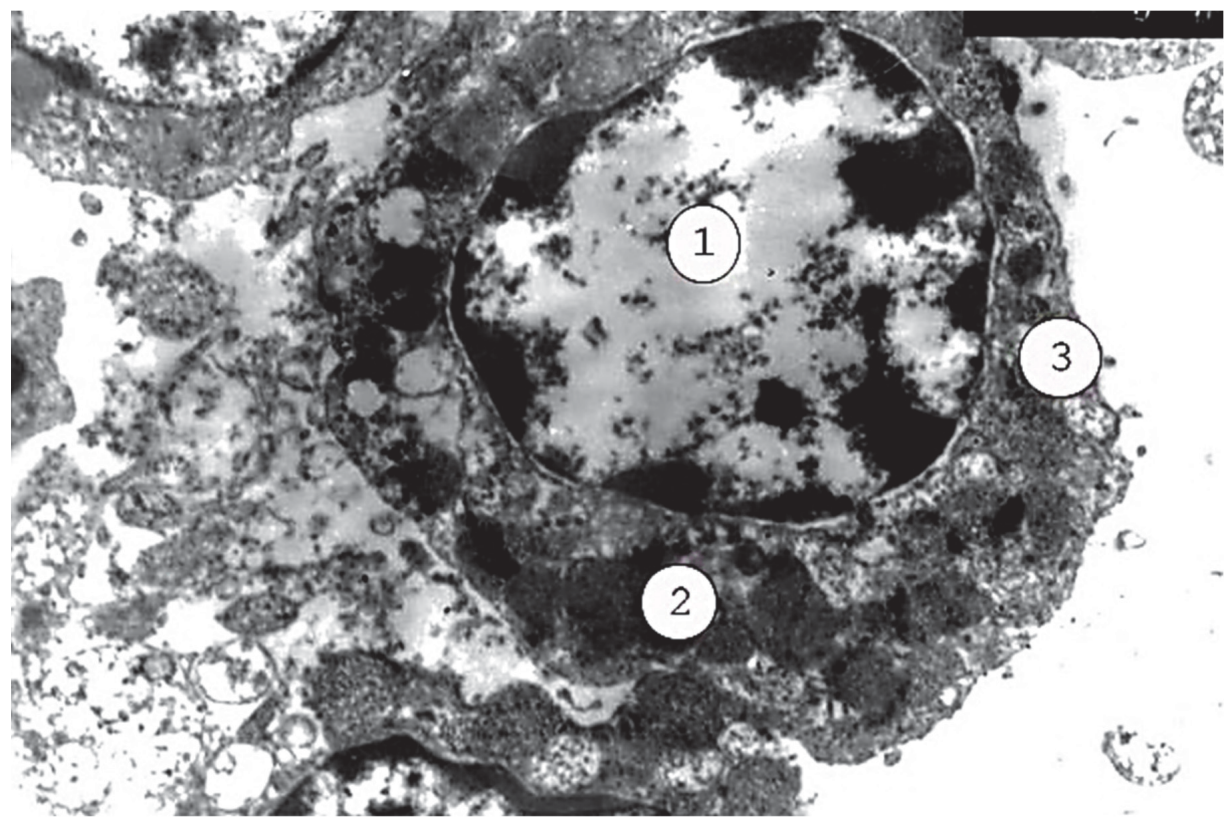

Fig. 6. Mast cell in parenchyma of the cervicothoracic lymph node of a domestic goose. Electronogram, $\times$ 13500: 1 - nucleus; 2 -granules in cell cytoplasm; 3 - cell cytoplasm

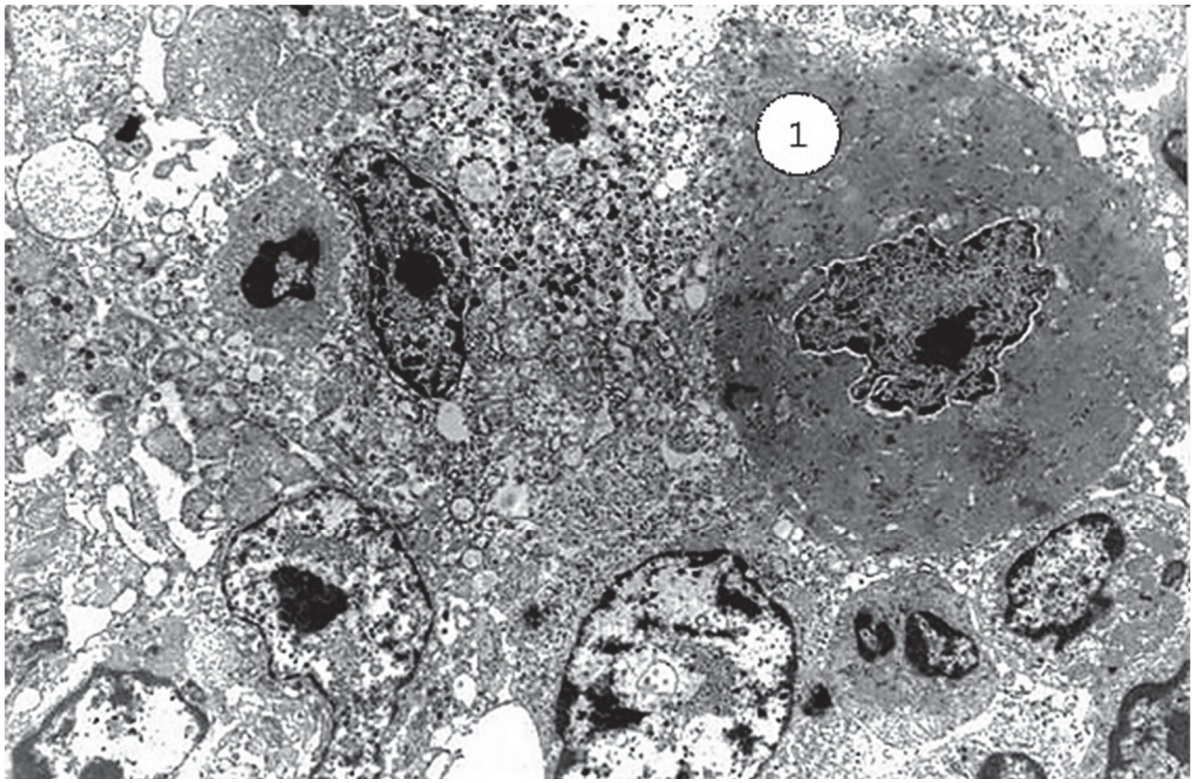

Fig. 7. Myoid cell (1) in parenchyma of the cervicothoracic lymph node of a domestic goose. Electronogram, $\times 6500$ 
The basis of the lymphoid tissue of parenchyma node is formed by a reticular tissue. The architectonics of its fibers varies in the varieties of lymphoid tissue. They form a fine mesh in the diffuse lymphoid tissue, cortex, and cerebral substance. In grid cells of lymphoid nodules, larger reticular fibers are often visible, and their center can be absent.

In imprint preparations of the cervicothoracic lymph nodes, in their parenchyma were found reticulocytes, lymphocytes, immunoblasts, plasma cells, macrophages, monocytes, mast cells, and myoid cells (Fig. 5-7).

The established cellular structure of parenchyma in studied lymph nodes testifies that these geese organs function as peripheral organs of immunogenesis.

The content of the parenchyma cells in the lymph nodes is not the same.

Among them, there are more lymphocytes $(79.51 \pm 2.73 \%)$. Among the lymphocytes, there are large, medium, and small.

The second place by cell content immunoblasts occupy $(18.73 \pm 1.05 \%)$.

The contents of plasmacytes, macrophages and their predecessors - monocytes is insignificant $(0.64 \pm 0.07 \%$ and $1.12 \pm 0.06 \%$ ).

The presence of lymphocytes, immunoblasts, macrophages, and plasma cells in parenchyma of the cervicothoracic lymph nodes of geese indicates that they function as peripheral organs of immunogenesis.

\section{Conclusions}

In mature domestic geese are constantly registered paired cervicothoracic lymph nodes and lumbar are absent. The cervicothoracic lymph nodes are predominantly spindle-shaped, less - conical. Their absolute and relative weights and sizes also depend on the weight and the size of the body of birds. The absolute weight of the left cervicothoracic lymph node of geese is $0.28 \pm 0.06 \mathrm{~g}$, the right $-0.28 \pm 0.06 \mathrm{~g}$. The relative weight of the right cervicothoracic lymph node of geese is $0.009 \pm 0.001 \%$, the left $0.008 \pm 0.001 \%$.

The cervicothoracic lymph nodes of domestic geese are formed by a connective tissue stroma, parenchyma, and the central sinus. The cortical substance of parenchyma is located on the periphery and the cerebral substance surrounds the sinus. The first is formed by lymphoid nodules and diffuse lymphoid tissue, and the second - only by the diffuse lymphoid tissue.

As a part of the parenchyma of the cervicothoracic lymph nodes, except for the cells, which contribute the function as a peripheral organ of immunogenesis (reticulocytes, immunoblasts, lymphocytes, plasmocytes, monocytes, and macrophages), mast cells and myoid cells are also identified. There are many lymphocytes among them $(79.51 \pm 2.73 \%)$.

The architectonics of reticular fibers in the parenchyma of the cervicothoracic lymph nodes varies in its individual components. In the diffuse lymphoid tissue of the lymph nodes, they form a fine mesh, on a periphery of lymphoid nodules of the reticular fibers there is a coarse mesh, and in their center - fibers are located solitary.

\section{References}

Avtandilov, G. G. (1990). Medytsynskaia morfometryia [Medical morphometry]. Moscow, Medicine, 248. (in Russian)

Berezina, E. A. (1979). K voprosu o morfo-funktsyonalnykh osobennostiakh lymfatycheskykh uzlov u ptyts [On the morpho-function- 
al features of the lymph nodes in birds]. Perm. (in Russian)

Ellenbergez, W. \& Baum, H. (1915). Handbuch der vergleichendenanatomie des Haustiere. Berlin, 1047.

Florensov, V. A. (1968). K voprosu o pervychnoi strukture lymfatycheskoho uzla $v$ fyloheneze pozvonochnykh [On the primary structure of a lymph node in the phylogeny of vertebrates]. Irkutsk honey Inst. Sat works on the morphology of the peripheral nervous and circulatory systems. Irkutsk, 158-166. (in Russian)

Florensov, V. A. \& Pestova, I. M. (1990). Ocherky Evoliutsyonnoi Ymmunomorfolohyy [Essays on the evolutionary immunomorphology]. Irkutsk. (in Russian)

Goralsky, L. P., Khomich, V. T. \& Kononsky, O. I. (2005). Osnovy histolohich-noi tekhniky i morfofunktsionalni metody doslidzhen $u$ normi ta pry patolohii [Bases gistologich noitehnikiimorfofunktsionalni methodological doslidzhen at normi that when patologii]. Zhytomyr: Polissya. (in Ukrainian)

Jolly, J. (1909-1910). Rehcerehessur les ganglions lymphatiques des oiseaux. Arch. d'Anat. Micr, Paris, 11:179-290.

Khomych, V. T. \& Melnyk, V. V. (2008). Topohrafiia i morfolohiia hrudo-shyinykh limfatychnykh vuzliv sviiskykh husei [Topography and morphology of cervicothoracic lymph nodes of domestic geese]. Naukovyi visnyk Lvivskoho natsionalnoho universytetu veterynarnoi medytsyny ta biotekhnolohii imeni SZ Gzhytskoho, 3-2(38):123-129. (in Ukrainian)

Kositsyn, I. I. (1958). K fylohenezu lymfatycheskoi systemy [By the phylogeny of the lymphatic system], Proceedings of the 6th All-Union Anatomy, histology and embryology Congress, Kyiv, (pp. 435-438). (in Ukrainian)

Kositsyn, I. I. (1959). Lymfatycheskaia systema [The Iymphatic system]. Perm. (in Russian)
Kositsyn, I. I. (1963). Lymfatycheskye uzly [Lymph nodes]. Perm. (in Russian)

Melnyk, V. V. (2010). Topohrafiia i morfolohiia hrudo-shyinykh limfatychnykh vuzliv sviiskykh kachok i husei [Topography and morphology of cervicothoracic lymph nodes of domestic ducks and geese]. Naukovyi visnyk Lvivskoho natsionalnoho universytetu veterynarnoi medytsyny ta biotekhnolohii imeni SZ Gzhytskoho, 2(44):240-244. (in Ukrainian)

Merkulov, G. A. (1969). Kurs patogistologicheskoj tekhniki [Course of patologogistologicheskoy techniques]. Moscow: Medicine. (in Russian)Pylypenko, M. E. \& Musienko, V. F. (1973). K voprosu o morfolohyy sheino-hrudnykh lymfouzlov utok $v$ norme $y$ eksperymente [On the morphology of the cervical and thoracic lymph nodes in normal ducks and experiment], Measures of disease control with farm animals: Inter-Institute Proceedings. Kharkiv, 88:116120. (in Ukrainian)

Sapin, M. R. (1977). Anatomyia soedynytelnotkannoho ostova lymfatycheskykh uzlov vzrosloho cheloveka [Anatomy of the connective tissue skeleton of lymph nodes adult]. Archive of AGE, 72(5):58-65. (in Russian)

Sapin, M. R. (1978). Lymfatycheskye uzly [Lymph nodes]. Moscow, Medicine. (in Russian)

Sapin, M. R., Yurina N. A. \& Etingen L. E. (1978). Lymfatycheskyi uzel (struktura y funktsyy) [Lymph node (structure and function)]. Moscow, Medicine. (in Russian)

Vershigora, A. E. (1990). Obshchaia ymmunolohyia [Overall immunology]. Vishchashk. (in Ukrainian)

Vinogradova, S. S. (1970). Rehyonarnye osobennosty konstruktsyy soedynytelno-tkannoho ostova lymfatycheskykh uzlov cheloveka [Regional structural features of connective tissue skeleton of human lymph nodes]. Archive of AGE, 45(12):45-54. (in Ukrainian) 


\section{В. В. Мельник, Т. С. Марковська (2020). ТОПОГРАФІЯ І МОРФОЛОГІЯ ГРУДО-ШИЙНИХ ЛІМФАТИЧНИХ ВУЗЛІВ ДОМАШНІХ ГУСЕЙ. Ukrainian Journal of Veterinary Sciences, 11(3): 65-74, https://doi.org/10.31548/ujvs2020.03.007}

Анотація. Встановлено, що в гусей постійно реєструються тільки грудо-шийні лімфатичні вузли. Грудо-шийні лімфатичні вузли гусей $\epsilon$ локальними скупченнями лімфоїдної тканини в стінці лімфатичних судин, що відводять лімфу від голови й шиї. Форма грудо-шийних лімфатичних вузлів у гусей неоднакова, більшість із них мають конусоподібну форму. Показники абсолютної, відносної маси і розмірів грудо-шийних лімфовузлів гусей залежать від маси й розмірів їхнього тіла. Грудо-шийні лімфовузли гусей утворені сполучнотканинною стромою, паренхімою й синусом. Сполучнотканинна строма представлена капсулою, яка є продовженням адвентиції й медії лімфатичної судини, а також трабекулами. Строма складається з пухкої волокнистої сполучної тканини, у якій розміщені міоцити і кровоносні судини. Синус є продовженням просвіту лімфатичної судини, а його стінка - продовженням ії інтими. Площа, яку займають сполучнотканинна строма, паренхіма й синус у вузлах досліджених птахів, неоднакова. Найбільшу площу займає паренхіма грудо-шийних лімфовузлів, яка, як і паренхіма лімфовузлів ссавців, утворена лімфоїдною тканиною. У паренхімі нечітко виділяються кіркова і мозкова речовини. Ї̈ кіркова речовина розташована на периферії, а мозкова - навколо синуса. Площа кіркової речовини переважає над мозковою. Кіркова речовина утворена дифрузійною лімфоїдною тканиною і лімфоїдними вузликами (переважно вторинними), а мозкова - тільки дифузійною лімфоїдною тканиною. Лімфоїдні вузлики круглої форми, оточені оболонками й залежно від діаметра розділені на три групи: великі, середні та малі. Основою лімфоїдної тканини паренхіми є ретикулярна тканина, яка складається з ретикулярних волокон. Архітектоніка волокон неоднакова в різних компонентах лімсоїдної тканини. Вони розташовані щільно, переплітаються і формують замкнуті осередки різної форми й невеликих розмірів. Клітинний склад паренхіми грудо-шийних лімфатичних вузлів гусей надзвичайно різноманітний. Це - ретикулоцити, лімфоцити, лімфобласти (імунобласти), макрофаги, моноцити, плазмоцити, тучні та міоїдні клітини. Склад цих клітин неоднаковий. Наявність у паренхімі грудо-шийних лімфатичних вузлів гусей лімфоцитів, лімфобластів (імунобластів), макрофагів і плазмоцитів вказує на те, що вони функціонують як перифреричні органи імуногенезу.

Ключові слова:гуси, шийно-груднілімфатичнівузли, сполучнотканинна строма, паренхіма, центральний синус, кіркова речовина, мозкова речовина, лімфоїдні фолікули, лімфоїдні клітини 